\title{
Nautical Almanac Equations and GPS Problems
}

\author{
J. M. Sharpey-Schafer
}

In the Forum section of the September 1994 Journal, the article 'The Author Replies' suggests that the almanac equations for many years ahead should be published. That is up to the Almanac Office. It would take many months to reinterpret my 20-year-old calculator.

Meanwhile, having received two other enquiries - one from a retiring Royal Marine Officer who intends to cruise around the world with GPS and a sextant back-up - the quick answer is to purchase a Casio FX-730 P already programmed for navigation sights. This pocket computer measures $6.5 \times 3$ inches and its essential Manual costs about $£_{70}$ (inc. vaT) from, amongst others, the East Berks. Boat Co., Henley-on-Thames. Any year can be entered in, very simply. At the same time, it is advisable to purchase the two types of spare 'watch' batteries, three in number, which are hard to come by, as it would be a pity to run out of power in mid-ocean 3 years later!

One comment about GPS : vide one expensive yacht totally wrecked in the Turks and Caicos in 1993 by misinterpreting GPS, and the 1994 tragedy of the Chinook helicopter that crashed on the Mull of Kintyre. It is all too easy to make some wrong initial setting or misinterpretation with electronic navaids. Which brings to mind an incident wherein my Navigator, while running an astern transit to enter Bahrain, altered course the wrong way - so easy to do - and bumped us over a shoal. This was smartly followed by his 'Starboard 20' for a right-angled turn to port, with a drying shoal close to starboard. The situation was saved by barging him off the voice pipe. That's life in the Nav lane. Like ' radar-assisted ship collisions ', there will be 'electronic nav disasters' due to overconfidence. As with computer viruses, there is a need for a human nav-scam-scan.

\section{KEY WORDS}

1. Astro navigation. 2. Satellite navigation. 